\section{Performance of Three Single Instrument Systems in the Preparation of Long Oval Canals}

Beatriz Serrato Coelho, Rodrigo Otavio Jatahy Ferreira do Amaral, Denise Piotto Leonardi, Bruno Marques-da-Silva, Yara Teresinha Corrêa Silva-Sousa, Fredson Marcio Acris de Carvalho, Flares Baratto-Filho
Department of Dentistry, Positivo University, Curitiba, PR, Brazil

Correspondence: Flares Baratto-Filho, Rua Professor Pedro Viriato Parigot de Souza, 5300, 81280-330 Curitiba, PR, Brasil. Tel: +55-41-3317-3406. e-mail:fbaratto1@gmail.com
This study aimed to evaluate the performance of the Wave One, Easy ProDesign Logic and One Shape systems in the preparation of long oval root canals. Forty-two mandibular incisors were randomized into three groups: Group I, Wave One Primary (W0) (\#25.08); Group II, Easy ProDesign Logic (EPL) (\#25.06) and Group III, One Shape (OS) (\#25.06). Microcomputed tomography scans were obtained pre- and post-preparation of the samples. Instrument fractures or loss of working length did not occur in any of the groups. There was a statistically significant difference in total root canal volume between the WO and EPL $(p<0.05)$ and OS systems $(p<0.05)$ The mean percentages of instrumented canal area in the middle thirds were $76.9 \%$ in the $W 0,62.3 \%$ in the EPL and $71.8 \%$ in the OS ( $p>0.05$ ). The OS system had the strongest correlation between volume increase and instrumented area $(R=0.63)$. The WO, EPL and OS systems presented mean preparation times of $2.13 \mathrm{~min}$, $0.54 \mathrm{~min}$, and $2.21 \mathrm{~min}(\mathrm{p}<0.05)$, respectively. All three systems enabled the safe preparation of long oval root canals. The WO system most effectively increased root canal volume, but it did not affect the instrumented areas. The OS system had the strongest correlation between volume increase and instrumented area, while the EPL system was the fastest.
Key Words: endodontics, micro-computed tomography, root canal preparation, rotary instrumentation.

\section{Introduction}

The evolution of root canal preparation involves constant technical modifications and frequent introduction of novel instruments to the market. Automated single-instrument systems are designed to reduce preparation time, instrument wear and cross-contamination risk. Despite their high cost, these systems offer several mechanical and biological advantages, such as the elimination of possible prior crosscontamination and decreased instrument fatigue associated with the single use (1).

The Wave One (WO) system (Denstply-Maillefer, Ballaigues, Switzerland), manufactured from M-wire alloy is available in three different sizes: small (\#21.06), primary (\#25.08) and large (\#40.08). It features a continuous tapered shape from the tip to the coronal end that ranges from 0.8 to $0.55 \mathrm{~mm}$. Its cross-section varies through the length of its active part. At the tip end, the cross-section is a convex triangle with a radial land. Throughout the remainder of the instrument, the cross-section changes to a convex triangle with a neutral angle in the region closest to the hilt, similar to the F2 instrument of the ProTaper system (2). The movement of the WO system is reciprocating; alternating anti-clockwise and clockwise angles ensure greater resistance $(1,3)$.

The One Shape (OS) system (Micro Mega, Besançon, France), composed of a 55-nickel-titanium (NiTi) alloy, is a single instrument that features continuous rotation for performing a complete root canal preparation. The instrument has a \#25 initial diameter and $0.06 \mathrm{~mm}$ taper and presents variable cross-sections across the length of its active portion (4). At the tip, the cross-section displays three sharp angles that merge along the instrument, forming only two angles, or S-shapes, in the region closest to the hilt. The pitch of the instrument is also variable (5).

Another system that aims to unite the concepts of a single instrument and continuous rotation is the Easy ProDesign Logic (EPL) (Easy Equipamentos Odontológicos, Belo Horizonte, MG, Brazil), with a nickel-titanium (NiTi) alloy and CM heat treatment, it is available in four different sizes: $25.06,30.05,35.05$ and $40.05 \mathrm{~mm}$ (6). The NiTi-base instrument features a modified S-shaped cross-section with two or three cutting blades and an inactive tip.

The shaping ability and clinical efficiency of single instrument systems have been widely studied (7-9). In particular, the WO system has been extensively evaluated, but few studies have compared its effectiveness in root canal preparations with the OS system $(4,5,10)$ and no studies investigated the EPL system.

The complex anatomy of the root canal system often presents a challenge to endodontic treatment success. Oval and long-oval canals are challenging in terms of cleaning, shaping and obturation, caused by the greater 
buccolingual dimension and consequent non-instrumented recesses $(7,11)$.

Preparation quality can be assessed by volume increase and the unprepared root canal surface area (12). Root canal preparation effectiveness is directly related to removal of the contaminated dentin to eliminate bacteria and their products (13-15). However, in oval and long-oval canals because of the non-instrumented regions, it is important to correlate the increased volume and instrumented areas, so that the possible excess removal of the mesiodistal dentin walls does not create a false impression that the entire canal was prepared.

This study evaluated the performance of the WO, EPL and $O S$ single instruments in the preparation of long oval canals by assessing volume increases and instrumented areas. Preparation times, working length maintenance and instrument fracture frequency were also observed.

\section{Material and Methods}

This study was approved by the Ethics and Research Committee of the Positivo University (Processo \#815.392/2014).

\section{Sample Selection and Specimen Preparation}

Human permanent mandibular incisors were used. For sample selection, all teeth were scanned with dental cone beam computed tomography (I-Cat ${ }^{\circledR}$; Kavo - Imaging Science International, Hatfield, PA, USA) and single oval and long oval-shaped canals (buccolingual diameter 2 times larger than the mesiodistal diameter at $5 \mathrm{~mm}$ from the root apex) (16-21) were selected, in a total of 42 teeth.

A \#10 K-type file (Dentsply-Maillefer) was used for negotiation and no resistance was observed. The specimens were stored in a $0.1 \%$ thymol solution at $4{ }^{\circ} \mathrm{C}$. After sample selection, the crowns were sectioned and the root canal length was standardized at $12 \mathrm{~mm}$ with an $11 \mathrm{~mm}$ WL.

The specimens were mounted on a custom device to obtain pre- and post-preparation scans in a standardized manner. A single specialist operator made all preparations using the X-Smart Plus motor (Dentsply-Maillefer) on this custom device. The specimens were randomized into the following three experimental groups:

Group I: Wave One Primary \#25.08 (WO) - This system was utilized according to the manufacturer's recommendations, with a pre-determined adjustment of the system's motor, introducing the instrument inside the root canal and three in-and-out pecking movements. The root canal was irrigated and the instrument was cleaned after each introduction until the working length was achieved.

Group II: Easy ProDesign Logic \#25.06 (EPL) - This system was utilized according to the manufacturer's recommendations. The instrument was introduced into the canal apically to reach the working length. The irrigation was made and the flutes of the instrument were cleaned after three in-and-out-movements (pecks). The motor parameters included a $950 \mathrm{rpm}$ speed and a $4 \mathrm{~N} / \mathrm{cm}^{2}$ torque (Fig. 1).

Group III: One Shape \#25.06 (OS) - This system was utilized according to the manufacturer's recommendations. It was introduced inside the root canal by in-and-out movements and under mild apical pressure to the point of resistance. The root canal was irrigated and the instrument was cleaned after each introduction and until the working length was achieved. The motor parameters included a 400 rpm speed and a $2.5 \mathrm{~N} / \mathrm{cm}^{2}$ torque .

During specimen preparation, between each use of the instrument, the canal was irrigated with $4 \mathrm{~mL}$ of $2.5 \% \mathrm{NaOCl}$ using a plastic syringe and a NavTip needle (NaviTip 30ga sideport; Ultradent, South Jordan, UT, USA) with concomitant aspiration. After irrigation, the patency was restored with a \#10 K-file. The final irrigation was performed with $6 \mathrm{~mL}$ of 17\% EDTA (PUI). Each instrument was discarded after three root canal uses (8,22-24).

\section{Micro-computed Tomography}

Pre- and post-instrumentation images were acquired by a SkyScan 1172 micro-computed tomography scanner (SkyScan, Kontich, Belgium) at $100 \mathrm{kV}$ and $100 \mu \mathrm{A}$ using an $\mathrm{Al}-\mathrm{Cu}$ filter. The pixel size was $12.8 \mu \mathrm{m}$ and the time
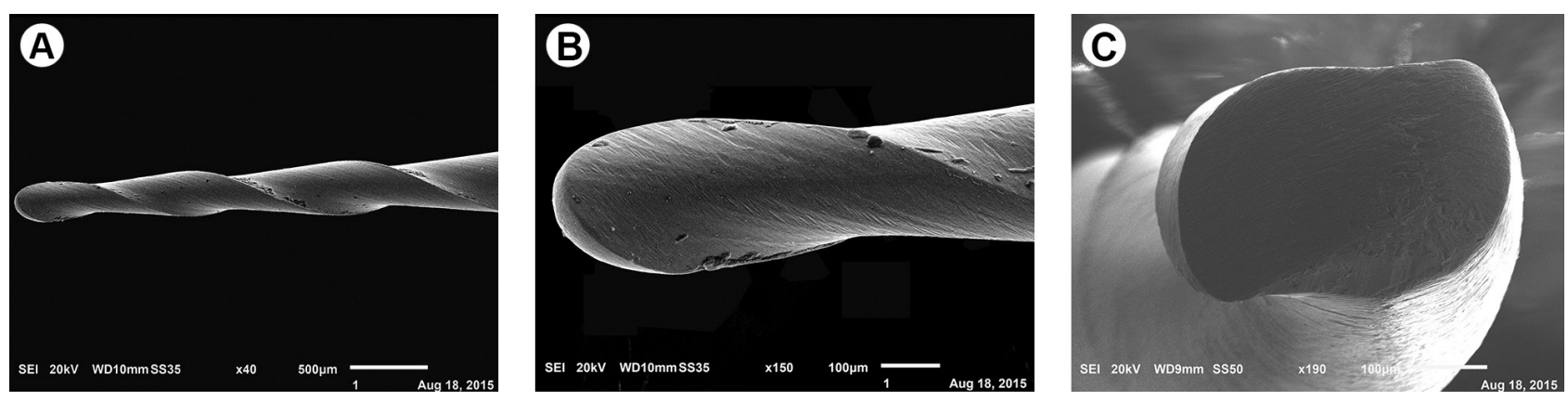

Figure 1. Easy ProDesign Logic instrument (25.06) (A), with an inactive tip (B), two cutting blades and a modified S-shaped cross-section (C). 
of exposure to the X-ray beam for each acquired image was $4 \mathrm{~s}$. The total acquisition time was 90 min per sample. The reconstruction of images in tomographic sections was performed using the NRecon program (SkyScan).

Briefly after the reconstructions, the tomographic sections were processed using CTAn software (SkyScan) and the total and third volumes of the canal were determined using CTVol software (SkyScan). The mean initial volume of the samples was $4.20 \pm 1.66 \mathrm{~mm}^{3}$. The volumes of the thirds were calculated by dividing the total number of tomographic slices by three.

Analysis of the instrumented canal area was performed at three set points: two points were defined within the limits between the cervical/middle (Region I) and the middle/apical thirds (Region III), while the third point was defined as the middle region between the other two points, consisting in the central region of the middle third (Region II) (Fig. 2).

The total canal area and instrumented area during preparation were measured using CTAn software. The area of the canal walls touched by the instrument was calculated in $\mathrm{mm}^{2}$. All images were analyzed at $250 \%$ amplification.

\section{Statistical Analysis}

The following parameters were evaluated: total root canal volume (by thirds), percentage of instrumented area and preparation time. Data were analyzed using Statistical Package for Social Sciences software (SPSS v. 20.0, IBM Inc., Chicago, IL, USA). Analysis of variance was utilized for single-factor analyses and the least significant difference test was used for multiple intergroup comparisons. Variable normality was assessed by the ShapiroWilk test.
Variables with asymmetric distributions were analyzed using the non-parametric Kruskal-Wallis test. Statistical significance was set at $p<0.05$. The Pearson productmoment correlation coefficient was used to analyze the correlation between root canal volume and the proportion of instrumented area.

\section{Results}

There was no instrument breakage or loss of working length in any group. The WO, EPL and OS systems presented mean total root volume increases of $1.89 \mathrm{~mm}^{3}, 1.05 \mathrm{~mm}^{3}$ and $1.04 \mathrm{~mm}^{3}$, respectively (Table 1). There was a statistically significant difference in total root canal volume between the WO and EPL $(p<0.05)$ and OS systems $(p<0.05)$ but not between the EPL and OS systems ( $p>0.05$ ).

In the cervical third the volume increase with the WO system was statistically different from that of the EPL system $(p<0.05)$ (Table 1). When middle-thirds were analyzed, there was a statistically significant difference between the WO and the EPL systems $(p<0.05)$, as well as between the WO and OS systems $(p<0.05)$ (Table 1). On the other hand, in the apical thirds there was a statistically significant difference between the WO system and each of the other two systems $(p<0.05)$ but no statistically significant difference between the EPL and OS systems ( $p>0.05$ ) (Table 1).

The WO, EPL and OS systems presented mean preparation times of $2.13 \mathrm{~min}, 0.54 \mathrm{~min}$ and $2.21 \mathrm{~min}$, respectively. The EPL system featured a significantly shorter preparation time than the WO and OS systems $(p<0.05)$.

There was no statistically significant difference in the proportion of instrumented area between the groups for
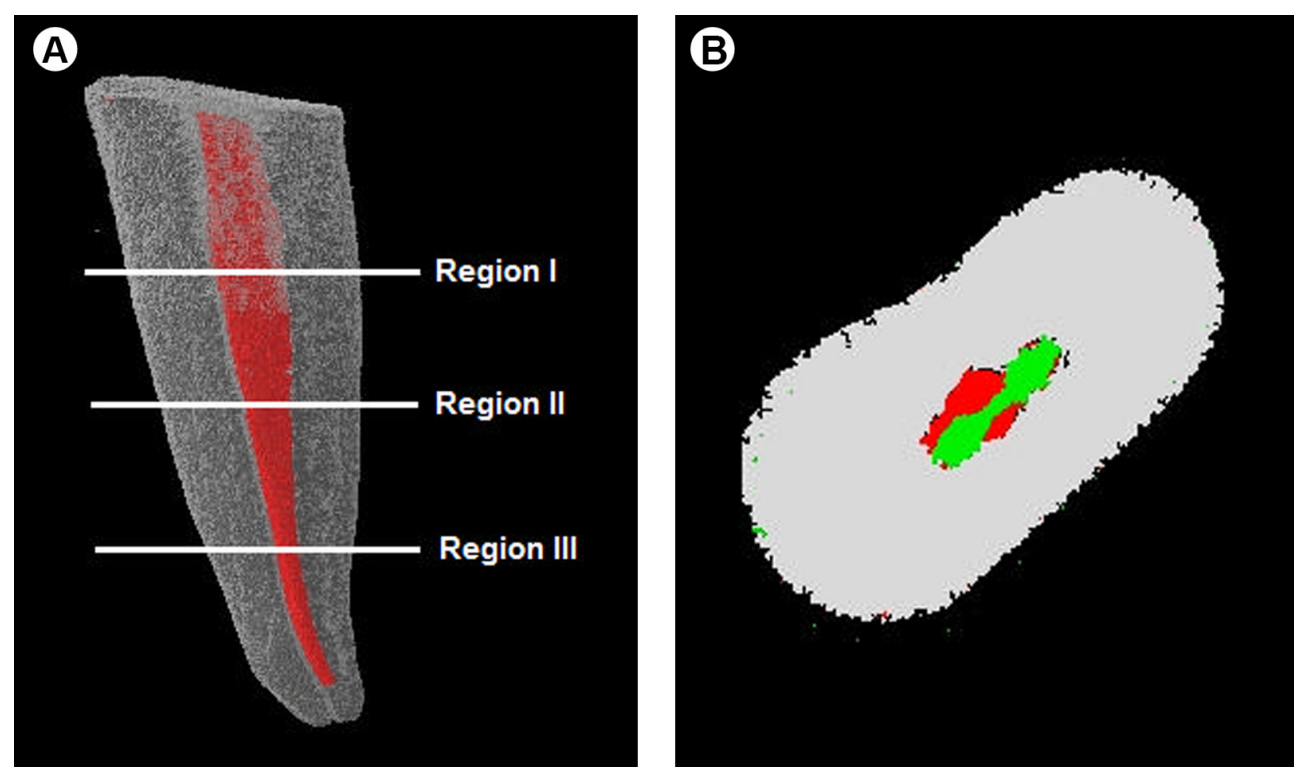

Figure 2. A: Regions used to calculate the porportion of instrumented area. B) Area pre (green) and post (red) instrumentation. 
any of the thirds $(p<0.05)$ (Table 2$)$. When the correlation between root canal volume (middle third) and the proportion of instrumented area (Region II) was calculated, the WO group and EPL groups demonstrated a moderate correlation $(R=0.40 ; R=0.32)$, while the OS group demonstrated a stronger correlation $(R=0.63)$ (Table 3$)$.

\section{Discussion}

In root canal preparation, the term "single file" refers to the utilization of a single instrument. The sterilization and re-use of these types of instruments is not recommended due to potential performance impairments. Each instrument was used in three samples, since they are usually used in multirooted teeth in clinical practice $(8,22-24)$. No instrument fractures were observed during specimen preparation. This finding supports the good results of previous studies of the WO and OS systems $(2,5,25,26)$ and now the EPL system.

The effectiveness of root canal preparation is directly related to the removal of contaminated dentin to eliminate bacteria and their products (13-15). Dentin removal increases root canal volume, which is essential to a successful preparation. In the present study, the WO group presented the greatest increase in total volume and in all thirds of $\vec{s}$ the root canal compared with the EPL and OS group. This finding may be explained by the greater taper $(0.08 \mathrm{~mm})$ of this system compared with the other two systems (0.06 $\mathrm{mm}$ ). However, it contradicts the results of Capar et al. (24), who did not report a statistically significant difference in performance between the WO and OS systems in resin blocks. This discrepancy in findings may be due to the methodological differences between the studies, as resin

Table 1. Mean volume increase $\left(\mathrm{mm}^{3}\right)$ in total root canal and canal third volumes

\begin{tabular}{lcccc}
\hline & Group (n=14) & Mean & p value* \\
\hline \multirow{3}{*}{ Total root canal } & WO & $1.89(0.85) \mathrm{a}$ & \\
& EPL & $1.05(0.54) \mathrm{b}$ & $\mathrm{p}<0.05$ \\
& OS & $1.04(0.48) \mathrm{b}$ & \\
Cervical third & WO & $1.20(0.48) \mathrm{a}$ & \\
& EPL & $0.73(0.39) \mathrm{b}$ & $\mathrm{p}<0.05$ \\
& OS & $0.86(0.55) \mathrm{ab}$ & \\
Middle third & WO & $0.60(0.31) \mathrm{a}$ & \\
& EPL & $0.27(0.19) \mathrm{b}$ & $\mathrm{p}<0.05$ \\
& OS & $0.28(0.17) \mathrm{b}$ & \\
Apical third & WO & $0.13(0.13) \mathrm{a}$ & \\
& EPL & $0.05(0.09) \mathrm{b}$ & $\mathrm{p}<0.05$ \\
& OS & $0.05(0.08) \mathrm{b}$ & \\
\hline
\end{tabular}

Statistically significant differences between the groups are indicated by different letters. blocks have a different hardness than human dentin (22).

Regarding the volume changes by root canal thirds, the WO system was superior to the other two systems for all evaluated thirds. The larger diameter of the instrument near the hilt, due to its larger taper $(0.08 \mathrm{~mm})$, enables a greater increase in the cervical region of the canal. This increase leads to improved reflux of irrigating solution and root canal debris. If reflux does not occur properly, dentin debris are accumulated and compacted in the apex during instrumentation within the canal. Furthermore, the system's larger taper in the first millimeter enables improved dental removal in this region.

The increase in apical third volume was proportionally less than in the other thirds in all three experimental groups. In some specimens, across all three groups there was a further reduction of the initial volume that probably resulted from dentin accumulation in this region. The projection of dentin debris into the apical portion is due to the pressure resulting from the use of a single instrument. Since singleinstrument systems are not utilized progressively, there is a greater pressure applied on the apical portion to achieve the working length (28).

Despite the root canal volume increase, it is still very difficult to instrument the entire area of the canal, especially those that are long ovals $(11,12)$. Instrumentation is particularly difficult in the middle region of the mandibular

Table 2. Percentage of instrumented area (\%)

\begin{tabular}{lcccc}
\hline Region & $\begin{array}{c}\text { Group } \\
(\mathrm{n}=14)\end{array}$ & Mean & $\begin{array}{c}\text { Standard } \\
\text { deviation }\end{array}$ & $\mathrm{p}$ value* \\
\hline I & WO & 79.8 & 18.8 & \\
& EPL & 63.6 & 18.4 & $\mathrm{p}>0.05$ \\
& OS & 79.2 & 18.4 & \\
II & WO & 76.9 & 23.8 & \\
& EPL & 62.3 & 19.5 & $\mathrm{p}>0.05$ \\
& OS & 71.8 & 21.4 & \\
& WO & 75.3 & 23.1 & \\
& EPL & 70.1 & 18.1 & $\mathrm{p}>0.05$ \\
& OS & 74.6 & 21.1 & \\
\hline
\end{tabular}

Table 3. Correlation between increased volume X instrumented area

\begin{tabular}{cccc}
\hline Group $(\mathrm{n}=14)$ & Volume $\left(\mathrm{mm}^{3}\right)$ & Area $(\%)$ & R value* \\
\hline WO & 0.60 & 76.9 & 0.40 \\
EPL & 0.27 & 62.3 & 0.32 \\
OS & 0.28 & 71.8 & 0.63 \\
\hline
\end{tabular}


incisors approximately $5 \mathrm{~mm}$ from the apex; therefore, this region was assessed in the current study. The mean diameter of this region in the buccolingual direction is approximately $0.81 \mathrm{~mm}$ (16). All the instruments used in the present study had diameters of approximately $0.49-0.57 \mathrm{~mm}$ at 5 $\mathrm{mm}$ from the apex. This explains the presence of the noninstrumented areas in the findings (mean instrumented area at the middle third was $62.3 \%$ in the EPL, $71.8 \%$ in $0 \mathrm{~S}$, and $76.9 \%$ in WO groups). The mean instrumented area in the WO system group (76.9\%) differed from the $64.7 \%$ reported by Gergi et al. (8), but this study was performed across the canal rather than at specific points as in the present study. Furthermore, in contrast to the current study, those authors analyzed the mesial roots of the mandibular molars.

The correlation analysis between increased volume and instrumented areas was performed only in Region II due to the greater flattening of the middle third of the mandibular incisors $(16,26)$. Comparing these data, the performance of the WO was $0.60 \mathrm{~m}^{3} \times 76.9 \%$, EPL was $0.27 \mathrm{~mm}^{3} \times 62.3 \%$ and OS was $0.28 \mathrm{~mm}^{3} \times 71.8 \%$, demonstrating that the increased volume does not indicate an increased percentage of instrumented area; rather, it negatively impacts tooth strength and fracture resistance.

There was no loss of working length in any specimen. This finding is in agreement with those reported by Saber et al. (26), who compared the maintenance of the working length between the WO and OS instruments (in addition to the Reciproc instrument), and Bürklein et al. (5).

In the present study, the preparation time included active instrumentation, irrigation time and maintenance of patency. The EPL system presented a shorter preparation time than the other two systems. This difference in preparation time may be associated with the instrument's preparation performance speed and the used maximum torque. Instruments such as the EPL system act on the canal with greater speed and torque $\left(950 \mathrm{rpm}, 4 \mathrm{~N} / \mathrm{cm}^{2}\right)$, reducing the preparation time and incidence of interruptions at the maximum torque, especially if compared with the OS system, which operates with a $2.5 \mathrm{~N} / \mathrm{cm}^{2}$ torque. However, high speed and torque may increase the risk of cyclic fatigue. Further studies are required to evaluate the resistance of these instruments.

The characteristics of this preparation should be considered when using this system in clinical practice, since some studies have suggested that bacterial elimination is strongly related with the $\mathrm{NaOCl}$ disinfection period. If the disinfection period is insufficient, disinfection may be ineffective, particularly in the dentinal tubules, increasing the risk of deterioration (30), thus justifying the application of higher concentrations of $\mathrm{NaOCl}$. Furthermore, the $\mathrm{WO}$ and OS systems showed similar preparation times, in contrast to the study by Saber et al. (26), who reported the OS system as the fastest, followed by the Reciproc and WO systems, respectively. The discrepancy between findings may be due to inter-study differences in the angle of curvature of the investigated teeth, since systems with different alloys operate differently in teeth with greater curvatures.

The WO system was the most effective at increasing root canal volume without affecting the remaining instrumented areas. The OS system had the strongest correlation between volume increase and instrumented area. The EPL system was the fastest. All three systems safely enabled the maintenance of working length without instrument fracture.

\section{Resumo}

Este estudo teve como objetivo avaliar o desempenho dos sistemas Wave One, Easy ProDesign Logic e One Shape no preparo de canais radiculares ovais. Quarenta e dois incisivos inferiores foram randomizados em três grupos: Grupo I, Wave One primary (WO) (\#25.08); Grupo II, Easy ProDesign Logic (EPL) (\#25.06) e Grupo III, One Shape (OS) (\#25.06). As amostras foram submetidas a microtomografia computadorizada antes e após o preparo. Não ocorreram fraturas de instrumento ou perda de comprimento de trabalho em qualquer dos três grupos. Houve diferença estatisticamente significante no volume total do canal radicular entre o WO e EPL. A média do percentual de área instrumentada do canal no terço médio foi $76,9 \%$ no grupo WO, $62,3 \%$ no grupo EPL e $71,8 \%$ no grupo OS $(p>0,05)$. 0 sistema OS teve a correlação mais forte entre 0 aumento de volume e área instrumentada $(R=0,63)$. Os sistemas WO EPL e OS apresentaram tempos de preparo médios de 2,13 $\mathrm{min}, 0,54 \mathrm{~min}$ e $2,21 \mathrm{~min}(p<0,05)$. Todos os três sistemas foram seguros no preparo canais radiculares ovais. 0 sistema WO foi mais eficaz no aumento do volume de canal, entretanto, isso não afetou as áreas instrumentadas. 0 sistema OS teve a correlação mais forte entre o aumento de volume e área instrumentada, enquanto o sistema EPL foi o mais rápido.

\section{References}

1. Yared G. Canal preparation using only one Ni-Ti rotary instrument: preliminary observations. Int Endod J. 2008;41:339-344.

2. Bürklein $S$, Hinschitza $K$, Dammaschke T, Schäfer E. Shaping ability and cleaning effectiveness of two single-file systems in severely curved root canals of extracted teeth: Reciproc and Wave One versus Mtwo and ProTaper. Int Endod J 2012;45:449-461.

3. Kim JW, Ha JH, Cheung GSP, Versluis A, Kwak SW, Kim HC. Safety of the factory preset rotation angle of reciprocating instruments. J Endod 2014;40:1671-1675.

4. Dhingra A, Ruhal N, Miglani A. Evaluation of single file systems Reciproc, Oneshape and Wave One using cone beam computed tomography - an in vitro study. J Clin Diagn Res 2015;9:ZC30-34.

5. Bürklein S, Benten S, Schäfer E. Shaping ability of different single-file systems in severely curved root canals of extracted teeth. Int Endod J 2013;46:590-597.

6. Easy Equipamentos Odontológicos [homepage]. Limas Easy ProDesign Logic. Available at: http://www.easy.odo.br/limas/limas-easyprodesign-logic/ .

7. Topcu KM, Karatas E, Ozsu D, Ersoy I. Efficiency of the Self Adjusting File, Wave One, Reciproc, ProTaper and hand files in root canal debridement. Eur J Dent 2014;8:326-329.

8. Gergi R, Osta N, Bourbouze G, Zgheib C, Arbab-Chirani R, Naaman A. Effects of three nickel titanium instrument systems on root canal geometry assessed by micro-computed tomography. Int Endod J 2015;48:162-170.

9. Park SK, Kim YJ, Shon WJ, You SY, Moon YM, Kim HC, et al.. Clinical efficiency and reusability of the reciprocating nickel-titanium instruments according to the root canal anatomy. Scanning 2014;36:246-251. 
10. Saleh AM, Gilani PV, Tavanafar S, Schafer E. Shaping ability of 4 different single-file systems in simulated S-shaped canals. J Endod 2015;41:548-552.

11. Wu M-K, Wesselink PR. A primary observation on the preparation and obturation of oval canals. Int Endod J 2001;34:137-141.

12. Busquim S, Cunha RS, Freire L, Gavini G, Machado ME, Santos M. A micro-computed tomography evaluation of long-oval canal preparation using reciprocating or rotary systems. Int Endod J 2015;48:1001-1006.

13. Schilder $\mathrm{H}$. Cleaning and shaping the root canal. Dent Clin N Am 1974;18:269-276.

14. Schäfer $\mathrm{E}$, Erler M, Dammaschke T. Comparative study on the shaping ability and cleaning efficiency of rotary Mtwo instruments. Part 2. Cleaning effectiveness and shaping ability in severely curved root canals of extracted teeth. Int Endod J. 2006;39:203-212.

15. Neves MA, Provenzano JC, Rôças IN, Siqueira JF. Clinical antibacterial effectiveness of root canal preparation with reciprocating singleinstrument or continuously rotating multi-instrument systems. J Endod 2016;42:25-29.

16. Wu M-K, Roris A, Barkis D, Wesselink PR. Prevalence and extent of long oval canals in the apical third. Oral Surg Oral Med Oral Pathol Oral Radiol Endod. 2000;89:739-743.

17. Keles A, Simsek N, Alcin H, Ahmetoglu F, Yologlu S. Retreatment of flat-oval root canals with a self-adjusting file: an SEM study. Dent Mater J 2014;33:786-791.

18. Ma J, Al-Ashaw AJ, Shen Y, Gao Y, Yang Y, Zhang C, et al.. Efficacy of ProTaper Universal Rotary Retreatment system for gutta-percha removal from oval root canals: a micro-computed tomography study. J Endod 2012;38:1516-1520.

19. Rechenberg DK, Paque F. Impact of cross-sectional root canal shape on filled canal volume and remaining root filling material after retreatment. Int Endod J 2013;46:547-555.

20. Pereira RD, Brito-Júnior M, Leoni GB, de Sousa-Neto MD. Evaluation of bond strength in single-cone fillings of canals with different crosssections. Int Endod J 2015. [Epub ahead of print]. doi: 10.1111/iej.12607.

21. Crozeta BM, Silva-Sousa YT, Leoni GB, Mazzi-Chaves JF, Fantinato

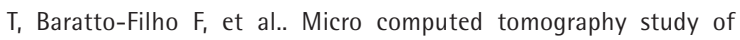

filling material removal from oval-shaped canals by using rotary, reciprocating and adaptive motion systems. J Endod. 2016. [Epub ahead of print]. doi: http://dx.doi.org/10.1016/j.joen.2016.02.005.

22. Lim LY, Park SJ, Kim HC, Min KS. Comparison of the centering ability of Wave-One and Reciproc nickel-titanium instruments in simulated curved canals. Restor Dent Endod 2013;38:21-25.

23. Gergi R, Arbab-Chirani R, Osta N, Naaman A. Micro-computed tomographic evaluation of canal transportation instrumented by different kinematics rotary nickel-titanium instruments. J Endod 2014;40:1223-1227

24. Tambe VH, Nagmode PS, Abraham S, Patait M, Lahoti PV, Jaju N. Comparison of canal transportation and centering ability of rotary Protaper, One Shape System and Wave One System using cone beam computed tomography: an in vitro study. J Conserv Dent 2014;17:561565.

25. Kim HC, Hwang YJ, Jung DW, You SY, Kim HC, Lee W. Shaping ability of single-file technique using reciprocating motion. Scanning. 2013;35:112-118.

26. Saber SEDM, Nagy MM, Schäfer E. Comparative evaluation of the shaping ability of Wave One, Reciproc and One Shape single-file systems in severely curved root canals in extract teeth. Int Endod J 2015;48:109-114.

27. Capar ID, Ertas H, Ok E, Arslan H, Ertas ET. Comparative study of different novel nickel-titanium rotary systems for root canal preparation in severely curved root canals. J Endod 2014;40:852-856.

28. Gambarini G1, Testorelli L, De Luca M , Milana V, Plotino G, Grande NM, et al.. The influence of three different instrumentation techniques on the incidence of postoperative pain after endodontic treatment. Ann Stomatol 2013;20;4:152-155.

29. Leoni GB, Versiani MA, Pécora JD, Sousa-Neto MD. Micro-computed tomographic analysis of the root canal morphology of mandibular incisors. J Endod. 2014;405:710-716.

30. Ferrer-Luque CM, Bejarano I, Ruiz-Linares M, Baca P. Reduction in Enteroccocus faecalis counts - a comparison between rotary and reciprocating. Int Endod J 2014;47:380-386.

Received September 13, 2015 Accepted January 11, 2016 